ploughing up for cereals should be improved as such, so that it can be ready for the plough in two or three years time. Further, every effort must be made to improve the quantity and quality of existing grass to compensate for the acreage lost to the plough.

The means of achieving these aims, Sir George maintains, is the ley, those of three years and upward making for a sound system of alternate husbandry, and the bulletin is largely devoted to describing methods which will most rapidly convert poor permanent grassland into good leys. Three main methods of procedure are given, namely, the sow. ing of seeds mixtures, with or without a cereal covering crop, directly on the prepared surface of the upturned sod, and the sowing of rape and Italian rye grass as a preparation for a subsequent ley mixture. The all-prevailing notion that a ley can only be economically established under a cereal nurse crop at the end of a rotation is shown to be contrary to facts, for experience has proved that newly broken grass is an excellent starting point and that a cover crop is not essential. The value of sowing pioneer crops such as Italian rye and rape on land which is at present unproductive is also strongly stressed, as it provides back end and early spring keep and will help to make the land sward- or cerealworthy at a later date. The bulletin supplies numerous details regarding manuring and seeds mixtures and gives examples of the experience of farmers from different parts of the country in support of the policy advocated.

\section{Family Allowances}

Is a pamphlet entitled "An Aylesbury Broadside" (price $3 d$.), the Lancet surveys the case for family allowances. The subject is dealt with mainly as a public health problem, for in 1938 there were at least 189,000 school-children in England and Wales suffering from malnutrition. Unfortunately, in most cases wages do not expand with the advent of children, and what sufficed for the family of one or two children becomes inadequate when there are three or more. Further, malnutrition in men is serious enough, but it is trivial in its effects on the race compared with ill-health in child-bearing women. Food requirements and the cost of adequate diets are discussed, and from the medical point of view the Lancet considers that there is an excellent case for paying a flat rate of 5s. for every child in the country. The principle of family allowances is actually admitted in the case of certain income-tax payers and in separation allowances for the families of soldiers, and a growing number of industrial firms have established family allowance schemes of their own. Various suggested schemes are outlined, namely, to place the whole onus on the employer, to let the State pay out of taxation, or a contributory scheme in which employers, workers and the State all take a share. A State scheme would probably cost $f 118,000,000$. Certainly a case seems to be made out for the payment of family allowances of the order of 5s, for at least the third and subsequent children.

\section{Economics of the State}

A Pamphlet, "The New Social Order: its Mechanism", by a group of scientific workers, which is edited by A. H. Mackmurdo, emphasizes the importance of the economic position and advocates the elaboration of an economic unit to organize distribution of resources upon an equitable scale (London: The C. W. Daniel Co. 6d.). In each State, the national economy would be based on a fixed price for the staple foodstuff, this fixing the price of all home-grown foods and, in turn, the price of all national goods and services, and each living wage would be measured upon this price-scale. The social mechanism to remove the paradox of potential plenty and actual poverty is regarded as involving three changes: a radical change in the mechanism of a commonwealth distribution; an instrument for measuring the distribution of the portions of this common wealth to be distributed to the members of the community as co-partners of it; and a regulative organ to control and guide the highly specialized organs of production, regulate the machinery of distribution and control all national imports and exports. The first change involves a new wage system and the disappearance of public or private ownership in the fruit of the common effort. The second involves the establishment of a new form of national money, and in the third, growth of the social service conception is essential, leading to the development of occupational organizations, which will regulate the economic affairs of the industry or occupation in the interest of the whole community.

\section{The School of Salerno}

In a paper read before the Section of the History of Medicine of the Royal Society of Medicine on June 25, Dr. H. P. Bayon referred to his previous communication on this subject (NATURE, March 30, 1940 , p. 507), and said that it was generally agreed that a broad stream of Hippocratic medicine could be traced from classical times to the present day. Hippocrates was mainly concerned with the observation of symptoms for prognostic purposes, while Galen seven centuries later made diagnosis subservient to treatment. During the following nine centuries the Hippocratic stream became a mere trickle, just recognizable in the writings of philosophers like Hrabanus. In the ninth century the practitioner of medicine, when not a monk, was a medicus who employed spells and charms and could scarcely read or write. In the East, on the other hand, physicians and surgeons were trained by learned teachers. At the time of the first Crusade the Masters of Salerno first arose, adopted the title of Magister like that of expounders of the law and taught by means of the excerpts and compilations of Moslem and Hebrew writers like Constantinus Africanus, who died about 1087.

The Salernitans established by example and precept that the practitioner of medicine should be a learned person, not only a skilled craftsman. They concentrated on the treatment of symptoms, made a timid attempt to learn anatomy, and, what is par- 